Prepared for the U.S. Department of Energy

under Contract DE-AC05-76RL01830

\title{
Development and Testing of a High Capacity Plasma Chemical Reactor in the Ukraine
}

Final Report for CRADA PNNL/311

With Campbell Applied Physics

\author{
RW Reilly
}

July 2012 


\title{
DISCLAIMER
}

This report was prepared as an account of work sponsored by an agency of the United States Government. Neither the United States Government nor any agency thereof, nor Battelle Memorial Institute, nor any of their employees, makes any warranty, express or implied, or assumes any legal liability or responsibility for the accuracy, completeness, or usefulness of any information, apparatus, product, or process disclosed, or represents that its use would not infringe privately owned rights. Reference herein to any specific commercial product, process, or service by trade name, trademark, manufacturer, or otherwise does not necessarily constitute or imply its endorsement, recommendation, or favoring by the United States Government or any agency thereof, or Battelle Memorial Institute. The views and opinions of authors expressed herein do not necessarily state or reflect those of the United States Government or any agency thereof.

\author{
PACIFIC NORTHWEST NATIONAL LABORATORY \\ operated by \\ BATTELLE \\ for the \\ UNITED STATES DEPARTMENT OF ENERGY \\ under Contract DE-AC05-76RL01830
}

Printed in the United States of America
Available to DOE and DOE contractors from the Office of Scientific and Technical Information,
P.O. Box 62, Oak Ridge, TN 37831-0062;
ph: (865) 576-8401
fax: $(865)$ 576-5728
email: reports@adonis.osti.gov

\begin{abstract}
Available to the public from the National Technical Information Service, U.S. Department of Commerce, 5285 Port Royal Rd., Springfield, VA 22161 ph: (800) 553-6847 fax: $(703) 605-6900$ email: orders@ntis.fedworld.gov online ordering: http://www.ntis.gov/ordering.htm
\end{abstract}

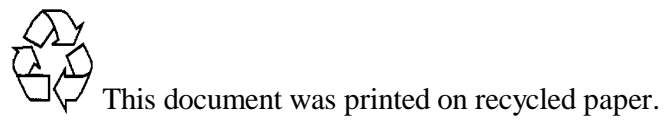




\section{Development and Testing of a High Capacity Plasma Chemical Reactor in the Ukraine}

Final Report for CRADA PNNL/311 with Campbell Applied Physics

Raymond W. Reilly

July 2012

Prepared for the U.S. Department of Energy under Contract DE-AC05-76RL01830

Pacific Northwest National Laboratory

Richland, Washington 99354 


\section{Table of Contents}

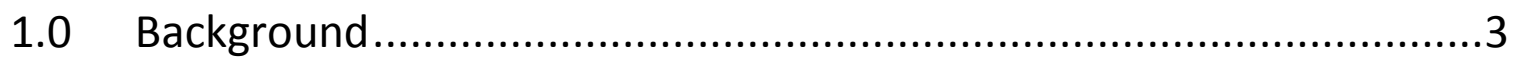

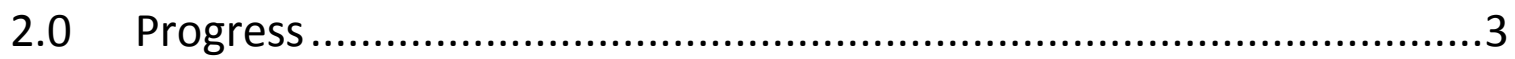

3.0 Commercial Partner's Evaluation of Project Success.......................4

4.0 Future Plans and Commercialization Activities .........................4

Inventions as a Result of this CRADA.......................................

6.0 Conclusion ................................................................... 


\subsection{Background}

The Global Initiatives for Proliferation Prevention (GIPP), National Nuclear Security Administration, U.S. Department of Energy has been working with former Soviet weapons institutes on nonproliferation for well over a decade. The primary mechanism has been the co-funding, with a U.S. commercial company, of a technology development project at the institute. The U.S. commercial company co-funds the project through a Cooperative Research and Development Agreement (CRADA) with the U.S. Department of Energy, represented by one of its national laboratories.

This project, Development and Testing of a High Capacity Plasma Chemical Reactor in the Ukraine was established at the Kharkiv Institute of Physics and Technology (KIPT). The associated CRADA was established with Campbell Applied Physics (CAP) located in El Dorado Hills, California. This project extends an earlier project involving both CAP and KIPT conducted under a separate CRADA. The initial project developed the basic Plasma Chemical Reactor (PCR) for generation of ozone gas. This project built upon the technology developed in the first project, greatly enhancing the output of the PCR while also improving reliability and system control.

\subsection{Progress}

This project has now been successfully completed. KIPT, in concert with CAP engineers, has redesigned the PCR to meet all of the design criteria established at the beginning of the project. Under its contract with DOE (through the Science and Technology Center of the Ukraine-STCU), KIPT delivered three high output PCRs to CAP, as well as five ozone sensors. The primary development goal was to extend the PCR output from $10 \mathrm{~g} \mathrm{O}_{3} /$ hour to $150 \mathrm{~g} \mathrm{O}_{3} /$ hour. This was achieved — the three delivered units are rated at $150 \mathrm{~g} / \mathrm{hour}, 160 \mathrm{~g} / \mathrm{hour}$ and $185 \mathrm{~g} / \mathrm{hour}$. The second important goal was to develop a low cost ozone sensor to support greater system control. KIPT developed a novel optical-based ozone sensor to provide reliable information on ozone production.

KIPT developed barrierless-type of ozone generators that are different from commonly used ozone generators with dielectric barrier in interelectrode gap. The advantages of the improved ozone generators are the following:

(1) Avoiding the dielectric barrier in discharge gap of plasma chemical reactor.

(2) Accidental electrical breakdown in the discharge gap does not cause disruption of the electrode system and the ozonizer remains operable.

(3) Highly stable ozone output.

(4) Low gas resistance.

(5) Modular system for both plasma chemical reactors and HV-pulsed power supply units.

(6) Modules are interchangeable.

(7) Equipped with remote control system.

(8) Improved ease of manufacture.

(9) Improved maintainability and durability. 
(10) Long-term operation capability via use of dehumidified air with dew point $+3 \mathrm{C}$ (only!) as a feed gas.

(11) Extended service interval and extremely long operational lifetime.

\subsection{Commercial Partner's Evaluation of Project Success}

From the final CRADA report submitted by Campbell Applied Physics:

It is the judgment of Campbell Applied Physics (CAP), that the High Capacity Plasma Chemical Reactor (HC PCR) CRADA was an exceptionally valuable endeavor. Commencing immediately after the successful conclusion of the PCR CRADA, it was noteworthy in several respects.

After only one year of $R \& D$, the HC PCR is now near commercial status. It is responsive to CAP's requirement for an ozone generator with sufficient output $(150 \mathrm{~g}$ O3/hr) to support both its existing Advanced Seawater Reverse Osmosis (ASWRO) desalination system and the O3CD system which treats Coal Bed Methane Produced Water (CBMPW) and is under development by a team consisting of CAP, KIPT, and Oak Ridge, Lawrence Livermore and Sandia National Laboratories.

The ozone sensor (monitor) is at a similar late state of development. It is currently in use as an HC PCR component, and standalone in CAP's laboratory and has been found to be highly competitive with sensors currently available in the marketplace.

\subsection{Future Plans and Commercialization Activities}

The final CRADA report submitted by Campbell Applied Physics provides the following information:

\section{Commercial Value of Progress Made on CRADA Project}

The ASWRO markets in the Middle East, Morocco and Mexico identified during the PCR CRADA remain, as does the joint venture in the Cape Verde Islands, which will provide water to the islands, and also provide CAP entre into water markets in the 15 ECOWAS countries on the West Coast of Africa.

CAP also anticipates major worldwide sales of its Ozone Capacitive Deionization (O3CD) systems. Near term, the market for O3CD CBMPW treatment equipment is estimated to be larger than the worldwide seawater desalination market.

In 2011 a new and highly profitable market emerged: the extraction of Rare Earth Elements (REE) from Phosphoric Acid production processes. A derivative of the O3CD Campbell Applied Physics combined with new technology available to CAP from Oak Ridge National Laboratory (ORNL) appears to be a solution to this growing US National Strategic problem and related business opportunity. 
The ozone sensors developed as HC PCR components and standalone items appear to be very competitive with existing sensors available in the US marketplace, both in terms of capability and price.

\section{Future CAP Commercialization Activities}

The HC PCR is a component of a derivative O3CD system developed with new technology from ORNL. It will be tested in extraction of Rare Earth Elements (REE) from Phosphoric Acid production processes.

The HC PCRs will in future be tested in other commercial applications which were previously considered, such as tire recycling, an application in which KIPT has considerable positive experience, and aquaculture.

\section{CAP/KIPT Future Relationship}

CAP and KIPT long considered that the CRADAs were merely the initial phases of a long-term relationship. In late-2011, they furthered this relationship when they established an STCU

Partnership, according to which KIPT will continue to carry out ozone related R\&D for CAP for the foreseeable future. At present, the R\&D projects include development of a power supply for the $\mathrm{CD}$ unit and $\mathrm{CD}$ regeneration and studying the physics of capacitive deionization.

CAP is also assisting KIPT to establish the capability to manufacture PCR units and components in Kharkov. In addition to providing products for its own customers, KIPT will act as a second source for PCR related products which CAP will manufacture in El Dorado Hills.

\subsection{Inventions as a Result of the CRADA}

Three suites of inventions were reported in separate invention disclosure reports to document the technical progress made under the CRADA (CAP) and STCU (KIPT) contracts:

(1) CAP invention disclosure report titled "High Capacity Plasma Chemical Reactor Invention Disclosure-Campbell Applied Physics,” 16 July 2012;

(2) KIPT invention disclosure report titled "High Capacity Plasma Chemical Reactor Letter of Improvements-Kharkiv Institute of Physics and Technology,” 12 July 2012 (\#65-00); and

(3) Joint CAP/KIPT invention disclosure report titled "Joint CAP/KIPT High Capacity Plasma Chemical Reactor Invention Disclosure,” 16 July 2012.

\subsection{Conclusion}

CRADA PNNL/311 is considered an outstanding success by all participating partners. The Plasma Chemical Reactor was brought to a state of commercial readiness, and is now being deployed by

CAP for advanced seawater reverse osmosis systems being deployed across the world, as well as for aquaculture water conditioning, and wastewater cleanup. KIPT has also found commercial success, 
deploying the system for swimming pool water treatment, water treatment aboard ships, seed treatments to enhance germination, and other applications.

A major element of this success is the tight, continuing connection that has developed between CAP and KIPT, wherein KIPT will continue conducting R\&D for CAP and will start to produce PCRs and subelements on a commercial basis for CAP. 